Published in final edited form as:

Cytotherapy. 2015 January ; 17(1): 3-17. doi:10.1016/j.jcyt.2014.05.019.

\title{
Cellular immunotherapy for pediatric solid tumors
}

\author{
MEENAKSHI HEGDE ${ }^{1,2,3}$, ALEXANDER MOLL ${ }^{1}$, TIARA T. BYRD ${ }^{1,2}$, CHRYSTAL U. \\ LOUIS $^{1,2,3}$, and NABIL AHMED ${ }^{1,2,3}$ \\ ${ }^{1}$ Center for Cell and Gene Therapy, Baylor College of Medicine, Houston, Texas, USA \\ ${ }^{2}$ Texas Children's Cancer Center, Baylor College of Medicine, Houston, Texas, USA \\ ${ }^{3}$ Department of Pediatrics, Baylor College of Medicine, Houston, Texas, USA
}

\begin{abstract}
Substantial progress has been made in the treatment of pediatric solid tumors over the past 4 decades. However, children with metastatic and or recurrent disease continue to do poorly despite the aggressive multi-modality conventional therapies. The increasing understanding of the tumor biology and the interaction between the tumor and the immune system over the recent years have led to the development of novel immune-based therapies as alternative options for some of these high-risk malignancies. The safety and anti-tumor efficacy of various tumor vaccines and tumorantigen specific immune cells are currently being investigated for various solid tumors. In early clinical trials, most of these cellular therapies have been well tolerated and have shown promising clinical responses. Although substantial work is being done in this field, the available knowledge for pediatric tumors remains limited. We review the contemporary early phase cell-based immunotherapy efforts for pediatric solid tumors and discuss the rationale and the challenges thereof.
\end{abstract}

\section{Keywords}

cell therapy; pediatric solid tumor; T cell; vaccine

\section{Introduction}

Outcomes for the majority of childhood cancers have improved substantially over the past 40 years. This was achieved because of the systematic consortium efforts largely focused on dose-intense multimodality and multi-agent interventions as well as improvements in the supportive measures needed. Despite this progress, the prognosis for children with refractory

Correspondence: Meenakshi Hegde, MD, or Nabil Ahmed, MD, MSc, Center for Cell and Gene Therapy, Baylor College of Medicine, 1102 Bates Street MC 3-3320, Houston, TX 77030, USA. mghegde@bcm.edu or nahmed@bcm.edu.

Disclosure of interests: The Center for Cell and Gene Therapy in engaged in a research collaboration with Celgene Inc, administered by Baylor College of Medicine, to develop chimeric antigen receptor-based therapeutics that is. CUL holds patents with or receives royalties from Cell Medica. MH and NA have patent applications in the field of T-cell and gene-modified T-cell therapy for cancer.

Uncited Reference and Table

Table I, 67.

The content is solely the responsibility of the authors and does not necessarily represent the official views of the National Institute of General Medical Sciences or the National Institutes of Health. 
and relapsed malignancies remains dismal. Furthermore, long-term toxicities of the intense chemotherapy/radiation therapy regimens are now becoming more evident with improving survival, highlighting the need for a qualitative change in our approach. Targeted therapies are being explored to overcome these toxic effects and to further improve survival. In this review, we discuss the various cellular immunotherapeutic approaches that are currently being investigated for some of the difficult-to-treat pediatric solid tumors.

For targeted cellular therapy of cancer, ideal candidate antigens are those that have high levels of expression on malignant cells with no or very low expression on normal cells. This would eliminate or minimize the systemic toxicities from on-target off-tumor effects (1). Cellular immunotherapy for cancers can be either active or passive. Active immunotherapy involves in vivo activation of the innate and adaptive immune system to induce a more sustained anti-tumor response. Autologous dendritic cells (DCs) loaded with tumor antigens ex vivo are most commonly used as antigen presenting cells (APCs). They evoke active specific anti-tumor responses by the host immune system. DCs are the most efficient APCs because they are able to present and cross-present antigenic peptides by both major histocompatibility complex (MHC) I and MHC II pathways, thereby stimulating both CD4+ and CD8+ lymphocytes (2). Although tumor vaccines have been largely well tolerated and shown encouraging results in early clinical trials, these studies have also highlighted some of the limitations of DC vaccines such as low frequency of antigen-specific $\mathrm{T}$ cells after vaccination (3). Furthermore, although the use of tumor vaccines for various adult malignancies has been investigated extensively over the past decade, the experience in the pediatric population has been limited.

For passive immunotherapy, immune cells such as tumor infiltrating lymphocytes (TILs), cytotoxic T lymphocytes (CTLs), natural killer cells (NK cells) and natural killer T cells (NKTs) can be generated ex vivo, expanded and infused in to the patient. Autologous or donor-derived T cells, NK and NKT cells can also be genetically engineered to express chimeric antigen receptors (CARs) that can specifically recognize and kill target antigenpositive tumor cells (4). CAR molecules consist of an extracellular antigen binding domain traditionally derived from the heavy and light chain variable regions of a monoclonal antibody and an intracellular signaling domain derived from the CD3- $\zeta$ chain. Costimulatory molecules such as CD28, 4-1BB or OX-40 can be incorporated to the signaling domain to enhance their performance $(5,6)$. Hence, CAR-redirected T cells combine the specificity of monoclonal antibodies with the cytolytic activity, potential for expansion and persistence ability of T cells. They induce tumor cell killing in a MHC-independent manner, thereby overcoming some of the mechanisms tumors employ to evade the host's immune system, such as down-regulation of MHC class I molecules or components of the antigen processing machinery.

\section{Tumors of the central nervous system}

Conventional therapies using debulking surgery, radiation and chemotherapy have not been effective in preventing tumor progression in high-grade glioma, as evidenced by the poor survival rates $(7,8)$. Brain tumors in general are significantly less responsive to systemic chemotherapy due, in part, to the presence of a blood-brain barrier that often limits the drug 
penetration into the central nervous system. Treatment failures are also often secondary to the development of primary or acquired drug resistance $(9,10)$. However, although improvements have been seen in some brain tumors such medulloblastoma (MB; 60-80\% overall survival at 5 years), treatment-associated morbidities continue to be substantial (11). Targeted immunotherapies have the potential to improve such outcomes while minimizing the treatment-related toxicities affecting the normal developing brain in children.

Cellular immune responses in glioma patients have long been known to be deficient as shown by lack of T-cell proliferation in response to phytohemagglutinin $(12,13)$. Other factors, such as the down-regulation of MHC class I and class II expression, along with lack of co-stimulatory molecules on glioma cells $(14,15)$, secretion of TGF $\beta$ and inhibitory prostaglandins by tumor cells (16-19) and infiltration of the tumor with regulatory $\mathrm{T}$ cells $\left(T_{\text {regs }}\right)(20,21)$, have been implicated in glioma-induced immunosuppression. These represent major hurdles to developing effective immunotherapeutic approaches for glioma patients. The mechanisms of immune-evasion in MB are not yet clearly understood $(22,23)$. Although it has been shown that the MHC class I antigen processing machinery components are down-regulated in MB cells, whether this contributes to the failure of immune surveillance is not well delineated. Despite the altered MHC expression, most brain tumors preserve some degree of antigen presentation to CTLs (24).

Most of the progress made in brain tumor immunotherapy can be attributed to the use of vaccines to induce an active cellular immunity against glioma. To generate glioma-specific DCs, the peripheral blood monocyte-derived DCs are pulsed ex vivo with tumor cell antigens in the form of tumor lysates, acid-eluted membrane peptides or by fusing the DCs with tumor cells (25-29). Single antigen-based vaccines have been shown to result in target antigen-negative tumor cell variants, a phenomenon seen less frequently with whole tumor cell-derived vaccines (30). Most investigators have used an intradermal approach to inject the DC vaccines, although the subcutaneous and the intravenous approaches have been tried as well. From either of these injection sites, DCs then migrate to the draining lymph nodes to activate CTLs $(31,32)$.

Results of multiple phase I/II clinical trials have now established the feasibility and safety of DC vaccines for brain tumors. Some of these studies in adults with malignant glioma have demonstrated objective clinical responses (29,33-35). Although research groups have administered DC vaccines according to different schedules, the total duration of vaccine therapy needed to maintain an anti-tumor immune response remains unknown. In recent years, investigators have pursued the use of adjuvant DC vaccines for children with highgrade glioma and other aggressive/recurrent brain tumors (25,36,37). In a clinical trial of 45 children with malignant brain tumors including high-grade glioma (HGG; $n=33$ ), MB/ primitive neuro-ectodermal tumor $(n=5)$, ependymoma $(n=4)$ and atypical rhabdoid teratoid tumor (ATRT; $n=3$ ), tumor lysate-loaded DC vaccines were well tolerated with no severe adverse events, and more favorable responses were noted in patients with HGG and ATRT than with those with MB/primitive neuro-ectodermal tumor (36). At a median followup of 35.7 months, 7 patients with HGG were alive (median overall survival 13.5 months; range 1.4-85.6 months), and 2 patients with ATRT were alive at 34.6 and 52.6 months of follow-up. Another prospective cohort comparison trial (HGG-IMMUNO) in 56 children 
and adults (age 7-77 years) with relapsed glioblastoma reported improved progression-free survival and overall survival after vaccination with autologous, mature, whole tumor cell lysate-loaded DCs as an adjuvant therapy after re-operation. Median overall survival from the re-operation was 9.6 months with a 2-year survival of $14.8 \%$. This study also showed that total resection and a younger age ( $<35$ years) to be predictors of better outcome (25). The addition of an adjuvant can potentially boost the immune response to a weakly immunogenic tumor-associated antigen (TAA). Adjuvants have minimal long-lasting immune effects of their own, but by augmenting the activity of DCs and lymphocytes, they can help sustain the specific immune response to the antigen. This may reduce the number of vaccine doses required to achieve the desired anti-tumor response. A single institution pilot study is currently underway to assess the safety and efficacy of vaccinations with HLA-A2-restricted glioma antigen-peptides in combination with Poly-ICLC (an immunostimulant that consists of carboxymethylcellulose, polyinosinic-polycytidylic acid and poly-L-lysine double-stranded RNA) and is enrolling children with newly diagnosed diffuse intrinsic pontine glioma (DIPG), HGG and recurrent unresectable low-grade glioma (Clinicaltrials.gov registry number NCT01130077). A phase I study conducted in adolescents and adults with HGG in collaboration with the HGG-IMMUNO group is using another immune response modifier (imiqui-mod) to investigate the anti-tumor immunity after intradermal injection of autologous DC vaccine after surgical resection (Clinicaltrials.gov registry number NCT01808820).

Whole tumor cell-derived DC vaccines contain tumor-specific as well as non-specific antigens and carry the risk of inducing immune response against the normal host tissue, although none has been reported in glioma trials so far. Efficacy of tumor antigen-specific vaccine is also being investigated. Rindopepimut is a peptide vaccine that evokes EGFRvIII (epidermal growth factor receptor variant III)-specific humoral as well as cellular immune response. Mutated EGFRvIII is a transmembrane glycoprotein with constitutive tyrosine kinase activity that plays an important role in tumorigenesis and development of chemoresistance $(38,39)$. Phase I/II trials using rindopepimut in adults with glioma have demonstrated improved progression-free survival and overall survival with minimal side effects $(40,41)$, and it is currently in a randomized phase III trial for adults with newly diagnosed glioblastoma (Clinicaltrials.gov registry number NCT01480479). EGFRvIII is a validated therapeutic target in pediatric HGG and DIPG (42-44). However, the safety and efficacy of EGFRvIII-specific vaccine therapy in children has yet to be studied. Another potential limitation of DC vaccines is the induction of tolerance after repeated, prolonged exposure to the antigen. The majority of the current vaccine trials use mature DCs because immature DCs are now known to be suboptimal for inducing immune response and are thought to induce tolerance $(28,45)$.

Cellular immunotherapeutics for brain tumors are at earlier stages of development $(46,47)$ and most of the available knowledge is based on pre-clinical data, but a number of phase I/II clinical trials are underway (Clinicaltrials.gov registry numbers NCT01109095, NCT01082926, NCT01454596). HER2 (human epidermal growth factor 2, also known as ErbB-2) is a transmembrane glycoprotein with tyrosine kinase activity and plays an important role in regulation of cell growth and differentiation (48). HER2 is expressed in up to $80 \%$ of glioblastoma (49) and medulloblastoma (50) but not on normal post-natal human 
brain (51). In a number of malignancies including glioma and medulloblastoma, overexpression of HER2 has been associated with poorer prognosis $(50,52)$. The monoclonal antibody (MAb) targeting HER2, trastuzumab, has been used effectively to treat tumors with gene amplification and over-expression of HER2, such as breast and ovarian carcinoma, but efficacy in over-expressing but non-gene amplified tumors, such as osteosarcoma, has been limited (53). Unlike trastuzumab, however, T cells modified to express HER2-specific CARs can efficiently recognize and kill tumor cells with even modest levels of HER2 expression. This has been shown in pre-clinical models of medulloblastoma, glioma and osteosarcoma in which HER2-specific CAR T cells induced regression of the experimental tumors and improved survival compared with the control mice treated with non-transduced T cells (54-56). In HER2 transgenic mice that expressed human HER2 as a self-antigen in brain and mammary tissues, CD8+ HER2-specific T cells infused in combination with lymphoablation and recombinant human interleukin (rhIL)-2 induced tumor regression with no evidence of autoimmunity, highlighting its potential as a safe and effective cancer therapy (57). In addition, adoptively transferred HER2 CAR T cells have also been shown to target primary glioblastoma stem cells (CD133+) and induce regression/resolution of autologous experimental tumors (55). The safety and efficacy of HER2-specific T cells is currently being investigated in a phase I trial using CMV-specific CTLs modified to express HER2-specific CAR (NCT01109095). This study also aims to simultaneously target the CMV protein pp65, expressed in $>65 \%$ of glioblastoma samples studied $(58,59)$. An added advantage of co-targeting CMV could be the survival signal provided by CMV-specific helper T cells in vivo (60). Another phase I study of T-cell therapy for HER2 positive malignancies employs a similar strategy, modifying the EBV-specific CTLs to express CAR molecules targeting HER2 (Clinicaltrials.gov registry number NCT00889954). This study is also designed to test whether rendering the adoptively transferred $\mathrm{T}$ cells resistant to the inhibitory effects to TGF- $\beta$ by transducing the T cells with the TGF- $\beta$ dominant negative receptor would improve their expansion and anti-tumor effects. Other surface-expressed glioma-specific antigens are also being targeted using ex vivo modified T cells. IL13Ra2 is a cell surface receptor with high affinity for IL13 and is differentially expressed on $>80 \%$ of high-grade gliomas $(61,62)$. IL13Ra2 has a short intracellular domain but lacks a signaling domain. However, recent studies in pancreatic and ovarian cancer cell lines have shown that IL13Ra2 may have a role in regulation of invasion and adhesion properties of cancer cells $(63,64)$. IL13Ra2 has been safely targeted using recombinant cytotoxin composed of human IL-13 and a truncated form of Pseudomonas exotoxin A (IL13-PE38QQR; Cintredekin besudotox) with encouraging results in adult HGG and the feasibility of convectionenhanced delivery of IL13-PE38QQR in pediatric patients with progressive DIPG and HGG is now being tested (Clinicaltrials.gov registry number NCT00880061). IL13-zeta-kine is an IL13Ra2-specific CAR molecule that uses IL13 as an antigen recognition domain. IL13zeta-kine redirected $\mathrm{T}$ cells have been shown to specifically target and kill differentiated high-grade glioma cells as well as glioma stem-like cancer-initiating cells in vitro and in animal models $(65,66)$. A phase I study of CD8+ T cells modified to express IL13-zetakine in combination with IL-2, for refractory/recurrent glioma in adult patients is now ongoing (Clinicaltrials.gov registry number NCT01082926). Although IL13Ra2 has been shown to be over-expressed in pediatric brain tumors (68-70), no cell therapy trials targeting IL13Ra2 are currently enrolling pediatric patients. 
Other potential targets for adoptive T-cell therapy of pediatric brain tumors include EGFRvIII and erythropoietin-producing hepatocellular carcinoma A2 (EphA2) $(43,68,69)$. Both EGFRvIII and EphA2 are known to be expressed in pediatric gliomas, and CARmodified $\mathrm{T}$ cells have been successfully generated against both these targets (70) (Clinicaltrials.gov registry number NCT01454596). Overall, results of the preclinical and early clinical studies of adoptive transfer of CAR-modified $\mathrm{T}$ cells for brain tumors have been fairly promising. However, factors such as the heterogeneous nature of these tumors and the inherent risk of tumor escape that leads to progression or recurrence make targeted therapy with $\mathrm{T}$ cells extremely challenging. In a pre-clinical study comparing bispecific $\mathrm{T}$ cell products simultaneously targeting HER 2 and IL13Ra 2 in glioblastoma to T cells targeting either HER2 or IL13Ra2 only, bispecific CAR T-cell products were found to improve tumor control and confer a significant survival advantage on the treated animals. This is likely because of the enhanced T-cell activation and to offsetting antigen escape (71). Combinational targeting of two or more tumor-restricted antigens and/or tumor and its microenvironment using $\mathrm{T}$ cells co-expressing distinct CARs or a bispecific CAR that consists of two antigen recognition domains in tandem (tanCAR) to achieve improved tumor control are potential strategies that could be incorporated in future studies $(71,72)$.

\section{Neuroblastoma}

Immunotherapy is an attractive option for patients with high-risk neuroblastoma because standard treatment with dose-intensive chemotherapy, surgery, radiation and biological maintenance therapy is associated with poor survival or the potential for significant longterm sequelae in those cured of disease. During the past 2 decades, researchers have been working on developing more targeted immunotherapeutic modalities for patients with neuroblastoma with the intent of improving outcome. Although the chimeric monoclonal antibody (MAb) ch14.18, targeting ganglioside GD2, has completed phase III trial within Children's Oncology Group, cellular therapies are currently being developed and tested in phase I/II trials. Neuroblastoma-specific tumor associated antigens targeted using immunotherapy, in clinical and pre-clinical testing, include mainly the disialoganglioside GD2, L1 cell adhesion molecule (L1-CAM), B7-H3 and O-acetyl GD2 (73-79). In a randomized phase III study of MAb targeting GD2, when compared with standard maintenance therapy using isotretinoin alone, the addition of ch14.18, IL-2 and GM-CSF was associated with an improvement in both 2-year event-free and overall survival (46\% versus $66 \%$ and $75 \%$ versus $86 \%$, respectively) (80).

Developing an effective vaccine for neuroblastoma has been a considerable challenge due to both biological disease heterogeneity and targetable antigenic expression. This biological diversity is exemplified by the fact that some lesions undergo spontaneous regression, whereas others are highly metastatic and minimally responsive to intensive therapy. Additionally, down-regulation of MHC, co-stimulatory molecules and TAAs by neuroblastoma cells may limit the effectiveness of any tumor-specific T cell immune response induced by the vaccine (81). Despite these obstacles, a number of studies have been reported in which tumor responses, including sustained complete remissions, have been observed. To tackle the issue of heterogeneity between and within neuroblastoma tumor samples, most tumor vaccines have been composed of cellular extracts or whole cell 
products that have the advantage of allowing multiple tumor antigens to be presented (82$85)$.

Whole cell vaccines are also amenable to genetic-modification to enhance anti-tumor immune responses; therefore, the investigators are now testing an allogeneic tumor cell vaccine modified to secrete both IL-2 and a T-cell recruiting chemokine called lymphotactin (86). When used alone in patients with relapsed or refractory neuroblastoma, subcutaneous injection of the tumor vaccine led to increased local infiltration of $\mathrm{CD}^{+}{ }^{+}$and $\mathrm{CD} 8^{+} \mathrm{T}$ cells, eosinophils and Langerhan cells. Increased NK cells and immunoglobulin G antibodies to the vaccine cell line were also detected within the peripheral blood. Of the 28 patients treated on study, there were 4 complete responses ( 2 sustained $>4$ years after vaccination), 1 very good partial response, 1 partial response and 5 patients with stable disease $(81,86,87)$. Currently investigators are evaluating whether the addition of a second, unmodified cell line expressing a distinct set of TAA in either the setting of minimal residual disease or in combination with metronomic chemotherapy will increase the breadth of the resulting immune response and therefore overall anti-tumor response in an ongoing phase I/II study of allogeneic tumor cell vaccination with oral metronomic Cytoxan that is currently recruiting patients with recurrent/refractory neuroblastoma (Clinicaltrials.gov registry number NCT01192555). Safety and efficacy of a bivalent vaccine containing two neuroblastomaassociated antigens, GD2L and GD3L, in combination with the adjuvant OPT-821 is currently being investigated in patients with relapsed high-risk neuroblastoma in second or subsequent remission (Clinicaltrials.gov registry number NCT00911560).

Adoptive cellular therapies for neuroblastoma have been more difficult to bring to the clinic compared with monoclonal antibodies or vaccines because of the technical, monetary and regulatory demands required for manufacture and administration. Nonetheless, clear potential advantages exist in preparing cellular products in an ex vivo environment free of immunosuppressive influences of established tumor. At this time, there are a limited number of studies testing the safety, immune responses and anti-tumor effects of adoptive cellular transfer with either NKs or genetically modified $\mathrm{T}$ cells. However, recent publications detailing successful clinical outcomes using T cells modified with CARs targeting tumor associated antigens in both adult and pediatric cancers (88-90) should lead to a further increase in phase I and II testing.

In the first study evaluating CAR T cells for patients with neuroblastoma, administration of CE7R CAR-expressing CD8 ${ }^{+}$clones targeting CD171 (L1, also known as L1CAM, is a transmembrane protein; it is a neuronal cell adhesion molecule belonging to $\mathrm{L} 1$ protein family) in patients with recurrent/refractory disease was found to be safe with no severe toxicities observed, and 1 of 6 patients had a partial, but unsustained, clinical response (77). Another neuroblastoma-associated antigen, GD2, has been successfully targeted using CAR modified $\mathrm{T}$ cells, and the long-term experience after the adoptive transfer of first-generation GD2-specific CAR T cells has been published. After infusion of more than 40 products in 19 patients, and with a median follow-up more than 5 years, the only treatment-related adverse events noted were low-grade fever and mild to moderate pain at known sites of disease in 3 patients. None of the subjects developed neurologic pain or dysfunction associated with GD2-MAb infusion $(60,70,89)$. Clinically, of 11 patients who had active 
disease at the time of GD2 $\mathrm{T}$ cell infusion, there was a 45\% response rate (complete, partial and stable disease). Three of 11 achieved complete remission, which was sustained for more than 5 years in two patients (personal communication with Dr. Louis). Immunologically, detection of GD2-specific CAR T cells beyond 6 weeks in patients with disease was associated with superior clinical outcome, and duration of persistence within the entire cohort was highly concordant with the percentage of $\mathrm{CD} 4^{+}$cells and central memory cells within the infused T-cell product (89). Investigators are now attempting to determine whether the $\mathrm{T}$ cells modified to express third-generation CARs consisting of CD28 and OX40 co-stimulatory domains will persist longer in vivo after adoptive transfer and hence have better therapeutic efficacy (Clinicaltrials.gov registry number NCT01822652). As the clinical use of second- and third-generation CARs has been associated with significant morbidity from cytokine storm and cytokine release syndrome, many groups are investigating ways to modify the T-cell product to allow for rapid cell death in the case of severe treatment related toxicities (91-93). For example, in the event of unwanted side effects from increased expansion of CAR T cells on NCT01822652, these T cells are also modified with inducible iCaspase 9 suicide gene that can be activated in vivo with the drug AP1903 that, upon activation, leads to programmed cell death $(88,94)$. Other strategies that have been investigated to improve the safety of adoptive cell therapy, such as genetic engineering of donor lymphocytes with herpes simplex virus thymidine kinase (HSV-TK) and transduction of T cells with human CD20, are not currently incorporated in any of the ongoing clinical trials for pediatric solid tumors (95-97). A pilot study is testing the safety and feasibility of adoptive immunotherapy with donor-derived, multi-virus specific CTLs expressing GD2-specific CAR in children with refractory/relapsed neuroblastoma who undergo allogeneic hematopoietic stem cell transplant (Clinicaltrials.gov registry number NCT01460901). This study aims to compare the frequency and expansion of allogeneic, tumor redirected, multi-virus cytotoxic T-cells to that of identically transduced, autologous EBV-specific T-cells infused in previous studies $(60,98)$.

\section{Pediatric sarcomas}

Sarcomas refer to the tumors derived from mesenchymal tissues, consisting of a wide range of tissue origins (99-101). Although the 5-year survival rates for pediatric sarcomas range from 60 to $70 \%$ with the currently available multimodality therapy, prognosis for children with recurrent or refractory sarcoma is particularly poor, ranging from 10 to $30 \%$. What was once an increasing survival rate has plateaued $(99,100,102)$. With the improved understanding of the interactions between the immune system and sarcomas (103), novel targeted therapies for childhood sarcomas are being developed. This section of the review seeks to highlight the cellular therapeutic approaches being investigated for pediatric sarcomas, specifically Ewing's sarcoma family of tumors (ESFT), rhabdomyosarcoma (RMS), osteosarcoma and synovial sarcoma.

Tumor vaccines are being investigated for various sarcomas; the most common agents tested are autologous tumor lysate (53) in conjunction with immunomodulation, DC vaccines pulsed with tumor lysate/peptides and peptide vaccines. The majority of the pediatric studies are small pilot studies, currently in phase I, with a limited number of patients enrolled. In an early study of tumor vaccine for pediatric sarcomas, peptide vaccination in combination with 
rhIL-2 infusion was demonstrated to be safe in patients with significant immunosuppression and bulky disease, but there was no notable clinical benefit (104). This could be due in part to the low immunogenicity of sarcoma antigens resulting in induction of a small number of antigen-specific T cells in vivo and, hence, an inadequate anti-tumor effect in the setting of large disease burden. A pilot study of consolidative immunotherapy was conducted in pediatric patients with high-risk sarcomas $(n=52)$ including metastatic or recurrent ESFT with $\mathrm{t}(11: 22)$ type 1 or 2 translocation and alveolar RMS [PAX3:FKHR fusion; $t(2: 13)$ translocation] (105). For the 30 patients who received immunotherapy, the 5-year overall survival was $43 \%$ with tolerable toxicity profile (1 patient developed grade 4 thrombocytopenia and 3 patients developed grade 3 neutropenia). After completion of the standard multimodal therapy, all 30 patients received influenza vaccine, similar doses of autologous T cells and DCs pulsed with appropriate tumor-derived breakpoint peptides as well as the control HPV16E7 peptide. Patients were stratified into three cohorts; cohorts 1 and 2 received moderate and low dose rhIL-2, respectively. Patients in cohort 3 did not receive rhIL-2. Influenza vaccine was used to determine whether the profoundly lymphopenic patients could respond to the vaccines; all patients showed influenza-specific immunity within 6 months of completing the cytoreductive therapy. However, measurable immune response to the vaccinating peptide was observed in 39\% (9 of 23) of the patients. HLA-A2 binding HPV16-derived peptide E7 was used as a control to assess the vaccineinduced immune response because the breakpoint peptides used in the study do not bind to all HLA alleles. Only 25\% (3 of 12) of HLA-A2+ patients on the study generated immune response to $\mathrm{E7}$, indicating that the low immune response rate observed was likely secondary to poor immunogenicity of the peptides in addition to the inadequate HLA binding. In another autologous DC vaccine study conducted in patients with refractory malignant solid tumors, patients received DC pulsed with tumor lysate $(n=3)$ or synthetic peptides $(n=2)$ against fusion proteins SYT-SSX2 or EWS-FLI-1, common in synovial sarcoma and ESFT, respectively (106). Of the five patients enrolled, one with Ewing's sarcoma showed a complete response and has been maintaining remission at 77 months of follow-up (106). Two patients exhibited stable disease for 1 month and 10 months before ultimately progressing (106).

Several other peptide vaccines have been and are currently being tested in pediatric patients with sarcoma. An ongoing randomized phase II trial is studying the efficacy of a trivalent vaccine against the $\mathrm{N}$-glycosylated gangliosides GM2, GD2 and GD3 in patients aged 16 years or older with metastatic sarcoma. In this study, patients in remission are randomized to receive either the vaccine with the adjuvant OPT- 821 or the adjuvant alone to assess the ability of the vaccine to elicit a sustained immune response against the earlier-mentioned antigens and prevent tumor recurrence (Clinicaltrials.gov registry number NCT01141491). Another phase I/II non-randomized trial investigating the efficacy of tumor lysate/KLH pulsed DC vaccine in combination with rhIL-7, administered soon after completion of chemotherapy in pediatric patients with Ewing's sarcoma, RMS or neuroblastoma, has recently been completed (Clinicaltrials.gov registry number NCT00923351). An autologous cancer testes antigen (CTA; MAGE-A1, MAGE-A3 and NY-ESO-1)-specific DC vaccine in combination with the hypomethylating agent decitabine is being investigated in pediatric patients with relapsed sarcomas and neuroblastoma (Clinicaltrials.gov registry number 
NCT01241162). CTAs are attractive targets for cellular immunotherapy because these antigens have been identified as being restricted to germline tissue expression, placental trophoblasts and a range of cancers including sarcomas and other pediatric solid tumors (53). Most of the ongoing immunotherapy trials target HLA A*02.01 associated epitopes because class I HLA type $A * 02.01$ is relatively common and $A * 02.01$ epitopes have been identified for some of the commonly expressed CTAs (53). Most of the knowledge regarding CTAs has been derived from studies conducted in synovial sarcoma, the majority of which express the CTA NY-ESO-1 (107). Of the larger sarcoma subtypes, osteosarcoma is known to express multiple cancer-testis antigens. CTAs are also a target of interest in adoptive cell therapy trials. Adoptive transfer of autologous T cells transduced with a T-cell receptor (TCR) directed against NY-ESO-1 after lymphodepletion with fludarabine and cyclophosphamide has been shown to be safe in adult patients(HLA-A2+) with NY-ESO-1positive metastatic melanoma $(n=11)$ and synovial sarcoma $(n=6)$. TCR-transduced T cells plus IL-2 induced objective clinical responses in four patients with synovial sarcoma and five patients with metastatic melanoma (108). Effects of adoptively transferred autologous TCR-transduced T cells targeting NY-ESO-1 following lymphodepletion with denileukin diftitox, fludarabine and cyclophosphamide is being investigated in a multiinstitutional phase I trial in HLA-A2+ patients with metastatic or recurrent synovial sarcoma (NCT01343043).

HER2 is another tumor-restricted antigen that is of particular interest for adoptive cell therapy of osteosarcoma. HER2 has been demonstrated to be over-expressed in a majority of the osteosarcomas and has been correlated with poor survival $(56,109,110)$. Taken together, these findings further support HER2 as a therapeutic target in osteosarcoma. A phase II trial was conducted by Children's Oncology Group evaluating the feasibility and safety of humanized monoclonal antibody trastuzumab (Herceptin) and chemotherapy in patients with HER2-overexpressing metastatic osteosarcoma (Clinicaltrials.gov registry number NCT00023998). Results of the study indicated that this treatment regimen was well tolerated, but after completion of the trial, its therapeutic benefit remains uncertain (53). However, genetically modified $\mathrm{T}$ cells redirected to HER2 have been demonstrated to induce tumor regression in both local and metastatic murine models of osteosarcoma (56). Furthermore, HER2-specific CAR T cells were also capable of eliminating tumor-initiating cells, both in vitro and in vivo, in a murine model of human osteosarcoma (110). A phase I clinical trial of autologous-HER2 CAR expressing T cells is currently underway in pediatric and adult patients with advanced HER2-positive sarcoma (Clinicaltrials.gov registry number NCT00902044). This study is designed to infuse T cells at increasing dose levels with the pre-determined interval between patients and allows for additional doses of $\mathrm{T}$ cells if the patient has stable disease or reduction in the tumor size, with the intent of evaluating the safety and efficacy of the HER2-specific T cells.

\section{Nasopharyngeal carcinoma}

Nasopharyngeal carcinoma (NPC) is a rare tumor with poor prognosis for those with a localregional bulky or metastatic disease at diagnosis (111). NPC arises from the epithelial cells of the nasopharynx, and almost all cases of pediatric disease are World Health Organization Type III (undifferentiated) tumors associated with Epstein-Barr virus (EBV) $(111,112)$. This 
allows for an alternative therapeutic approach using EBV antigens as immunotherapeutic targets for cell-based therapy. Polyclonal autologous EBV-specific CTLs have shown promising results in the treatment of relapsed EBV-positive NPC with objective clinical responses seen more often in patients with low disease burden (113-115). In a cohort of 23 patients with recurrent/refractory NPC (12 of 23 patients aged <20 years at infusion), $62 \%$ ( 5 of 8 ) of the patients treated in their second or subsequent remission remained disease-free at a follow-up of 17 to 75 months; of those with active disease at infusion, 48.7\% (7 of 15) had either a complete or partial response (116). No significant or dose-limiting toxicities were observed in either group (116). However, as seen with many other solid tumor studies, there was a lack of in vivo CTL expansion seen in NPC patients after adoptive transfer of EBV-specific CTL. With a hypothesis that the lack of expansion may be causing the limited anti-tumor activity in those with bulky disease, investigators have studied two methods to overcome this issue: the use of CD45 MAbs before the T-cell infusion as an alternative to lymphodepleting chemotherapy and the use of re-induction chemotherapy to decrease the tumor burden before adoptive transfer. Administration of CD45 MAbs led to an increase in the expansion and persistence of adoptively transferred EBV-specific CTL. It was also associated with clinical benefits including a complete response and prolonged stable disease in patients with increased expansion and persistence of infused CTLs (117). The use of reinduction chemotherapy with docetaxel and carboplatin before autologous EBV-specific Tcell infusion is ongoing and actively recruiting patients (Clinicaltrials.gov registry number NCT 00953420).

To improve these results, investigators have also modified their manufacturing process to develop CTLs that target LMP-1 and LMP-2, the most common EBV antigens seen in NPC (113). The safety and the anti-tumor activity of LMP-1 and LMP-2 specific T cells, in both the autologous as well as allogeneic (most closely HLA-matched) setting, are now being investigated in phase I trials (Clinicaltrials.gov registry numbers NCT00516087 and NCT01447056). Expression of these EBV-specific antigens on tumor cells also makes NPC an ideal disease to be treated using EBV-specific vaccines. Its therapeutic application is being investigated in clinical trials for adults with NPC (Clinicaltrials.gov registry numbers NCT01800071 and NCT0104405).

\section{Miscellaneous cell-based approaches}

NK cells are known to play an important role in host anti-tumor immunity through their direct cytotoxic effect on the tumor cells as well as mediation of antibody-dependent cellular toxicity. Recently, adoptive transfer of donor-derived NK cells has been of interest for therapeutic use in childhood cancers because of their potential "graft versus tumor" effect. KIR-mismatched (killer immunoglobulin-like receptors) NK cells from haploidentical donors have been observed to improve survival in adult patients with acute myeloid leukemia (AML) (118) as well a small number of children with refractory solid tumors (119). When HLA ligands against the inhibitory KIRs present in the donor are lacking in the recipient, cells without the inhibitory ligand may trigger the NK cell activation, thereby associating the enhanced alloreactivity of NK cells with the anti-tumor effect (119). Although the potential for the therapeutic application of NK cells is mainly being tested in hematologic malignancies, a few ongoing early clinical trials are also investigating the role 
of autologous and allogeneic NK cells in pediatric solid tumors (Table II). Safety and efficacy of haploidentical donor-derived NK cell infusion post-transplant (Clinicaltrials.gov registry number NCT00582816) and after conditioning chemotherapy with cyclophosphamide and fludarabine (Clinicaltrials.gov registry number NCT00640796) are being investigated in refractory/recurrent solid tumors in children and adolescents, particularly ESFT and rhabdomyosarcoma. NKTs are an evolutionary-conserved subset of T cells characterized by expression of an invariant TCR a-chain (Va24-Ja18) $(73,78,79,120)$. NKTs exert their anti-tumor activity by direct cytotoxic effect on CD1-d+ cells or indirectly by activation of the NK cells $(121,122)$. Although majority of the human solid tumors do not express CD1-d, nearly half of the me-dulloblastoma tumor specimens in a recent study were reported to have uniform surface expression of CD1-d (significantly higher levels in the Sonic Hedgehog molecular subgroup) (123). In this pre-clinical study, intracranial injections of NKTs induced regression of orthotopic medulloblastoma xenografts in NOD/SCID mice (123). NKTs have also been shown to suppress tumor growth by killing the CD1-d+ tumorassociated monocytes/macrophages (TAMs) in pre-clinical models of human neuroblastoma (122). Furthermore, NKTs genetically modified to express GD2-specific CARs have shown promising anti-tumor activity in pre-clinical models (Heczey et al, presented at the 2013 American Society of Gene and Cell Therapy Annual Meeting, unpublished). Lymphokineactivated killer (LAK) cells are tumoricidal effectors derived from the in vitro stimulation of a subpopulation of peripheral CD8+ cells with high concentration of IL-2. Unlike LAK cells, tumor infiltrating lymphocytes (TILs) induce tumor cell killing in a MHC-restricted manner by recognizing the tumor antigen expressed on the cell surface in association with the MHC class I molecule. Although use of ex vivo expanded LAK cells and TILs for cancer therapy have been investigated in various adult malignancies (124-126), their potential therapeutic use in children is yet to be studied.

\section{Summary}

Cellular immunotherapy using active immunization or adoptive transfer of immune effector cells may provide less toxic therapeutic options for children with solid tumors. Cell therapy can potentially generate additional sustained clinical responses by using alternate pathways of tumor-cell killing. There have been some success stories. However, more concerted efforts and multi-institutional collaborations are required to have adequate number of patients to appropriately power these studies and better assess the treatment efficacy. Our challenge is to firmly establish the efficacy of these approaches, continue to safely improve their anti-tumor activity and identify ways to integrate them with the current multimodality treatments. The more we learn about the immune system and its role in tumorigenesis, in conjunction with tumor biology, the better equipped we will become in developing effective targeted cell-based therapies for pediatric solid tumors.

\section{Acknowledgments}

The authors received funding from the Alliance for Cancer Gene Therapy, Alex's Lemonade Stand Pediatric Cancer Foundation, CureSearch for Children's Cancer (National Institutes of Health/National Cancer Institute grant P01 CA094237), Sidney Kimmel Foundation for Cancer Research Scholar Award, Solving Kids' Cancer, and the Stand Up to Cancer (SU2C)-St. Baldrick's Pediatric Cancer Dream Team Grant. TTB was supported by National Institutes of Health grants 5T32HL092332 (to Professor Helen E. Heslop) and by T32GM088129 from the National Institute of General Medical Sciences. 


\section{References}

1. Orentas RJ, Lee DW, Mackall C. Immunotherapy targets in pediatric cancer. Front Oncol. 2012; 2:3. [PubMed: 22645714]

2. Rock KL, Gamble S, Rothstein L. Presentation of exogenous antigen with class I major histocompatibility complex molecules. Science. 1990; 249:918-21. [PubMed: 2392683]

3. Capitini CM, Mackall CL, Wayne AS. Immune-based therapeutics for pediatric cancer. Expert Opin Biol Ther. 2010; 10:163-78. [PubMed: 19947897]

4. Eshhar Z, Waks T, Gross G, Schindler DG. Specific activation and targeting of cytotoxic lymphocytes through chimeric single chains consisting of antibody-binding domains and the gamma or zeta subunits of the immunoglobulin and T-cell receptors. Proc Natl Acad Sci U S A. 1993; 90:720-4. [PubMed: 8421711]

5. Carpenito C, Milone MC, Hassan R, Simonet JC, Lakhal M, Suhoski MM, et al. Control of large, established tumor xenografts with genetically retargeted human T cells containing CD28 and CD137 domains. Proc Natl Acad Sci U S A. 2009; 106:3360-5. [PubMed: 19211796]

6. Pule MA, Straathof KC, Dotti G, Heslop HE, Rooney CM, Brenner MK. A chimeric T cell antigen receptor that augments cytokine release and supports clonal expansion of primary human $\mathrm{T}$ cells. Mol Ther. 2005; 12:933-41. [PubMed: 15979412]

7. Cohen KJ, Pollack IF, Zhou T, Buxton A, Holmes EJ, Burger PC, et al. Temozolomide in the treatment of high-grade gliomas in children: a report from the Children's Oncology Group. Neuro Oncol. 2011; 13:317-23. [PubMed: 21339192]

8. MacDonald TJ, Aguilera D, Kramm CM. Treatment of high-grade glioma in children and adolescents. Neuro Oncol. 2011; 13:1049-58. [PubMed: 21784756]

9. Feun LG, Savaraj N, Landy HJ. Drug resistance in brain tumors. J Neurooncol. 1994; 20:165-76. [PubMed: 7807193]

10. Phillips PC. Antineoplastic drug resistance in brain tumors. Neurol Clin. 1991; 9:383-404. [PubMed: 1682794]

11. McNeil DE, Cote TR, Clegg L, Rorke LB. Incidence and trends in pediatric malignancies medulloblastoma/primitive neuroectodermal tumor: a SEER update. Surveillance Epidemiology and End Results. Med Pediatr Oncol. 2002; 39:190-4. [PubMed: 12210449]

12. Wood GW, Morantz RA. In vitro reversal of depressed T-lymphocyte function in the peripheral blood of brain tumor patients. J Natl Cancer Inst. 1982; 68:27-33. [PubMed: 6172627]

13. Wood GW, Morantz RA. Depressed T lymphocyte function in brain tumor patients: monocytes as suppressor cells. J Neurooncol. 1983; 1:87-94. [PubMed: 6236289]

14. Anderson RC, Anderson DE, Elder JB, Brown MD, Mandigo CE, Parsa AT, et al. Lack of B7 expression, not human leukocyte antigen expression, facilitates immune evasion by human malignant gliomas. Neurosurgery. 2007; 60:1129-36. discussion 1136. [PubMed: 17538388]

15. Ito A, Shinkai M, Honda H, Wakabayashi T, Yoshida J, Kobayashi T. Augmentation of MHC class I antigen presentation via heat shock protein expression by hyperthermia. Cancer Immunol Immunother. 2001; 50:515-22. [PubMed: 11776373]

16. Kuppner MC, Hamou MF, Sawamura Y, Bodmer S, de Tribolet N. Inhibition of lymphocyte function by glioblastoma-derived transforming growth factor beta 2. J Neurosurg. 1989; 71:211-7. [PubMed: 2545842]

17. Nakano Y, Kuroda E, Kito T, Yokota A, Yamashita U. Induction of macrophagic prostaglandin E2 synthesis by glioma cells. J Neurosurg. 2006; 104:574-82. http://dx.doi.org/10.3171/jns. 2006.104.4.574. [PubMed: 16619662]

18. Platten M, Wick W, Weller M. Malignant glioma biology: role for TGF-beta in growth, motility, angiogenesis, and immune escape. Microsc Res Tech. 2001; 52:401-10. [PubMed: 11170299]

19. Siepl C, Bodmer S, Frei K, MacDonald HR, De Martin R, Hofer E, Fontana A. The glioblastomaderived $\mathrm{T}$ cell suppressor factor/transforming growth factor-beta 2 inhibits $\mathrm{T}$ cell growth without affecting the interaction of interleukin 2 with its receptor. Eur J Immunol. 1988; 18:593-600. [PubMed: 2452745] 
20. Grauer OM, Nierkens S, Bennink E, Toonen LW, Boon L, Wesseling P, et al. CD4+FoxP3+ regulatory $\mathrm{T}$ cells gradually accumulate in gliomas during tumor growth and efficiently suppress antiglioma immune responses in vivo. Int J Cancer. 2007; 121:95-105. [PubMed: 17315190]

21. Heimberger AB, Abou-Ghazal M, Reina-Ortiz C, Yang DS, Sun W, Qiao W, et al. Incidence and prognostic impact of FoxP3+ regulatory T cells in human gliomas. Clin Cancer Res. 2008; 14:5166-72. [PubMed: 18698034]

22. Byrd T, Grossman RG, Ahmed N. Medulloblastoma-biology and microenvironment: a review. Pediatr Hematol Oncol. 2012; 29:495-506. [PubMed: 22742590]

23. Sonabend AM, Ogden AT, Maier LM, Anderson DE, Canoll P, Bruce JN, Anderson RC. Medulloblasoma: challenges for effective immunotherapy. J Neurooncol. 2012; 108:1-10. [PubMed: 22173741]

24. Raffaghello L, Nozza P, Morandi F, Camoriano M, Wang X, Garre ML, et al. Expression and functional analysis of human leukocyte antigen class I antigen-processing machinery in medulloblastoma. Cancer Res. 2007; 67:5471-8. [PubMed: 17545629]

25. De Vleeschouwer S, Fieuws S, Rutkowski S, Van Calenbergh F, Van Loon J, Goffin J, et al. Postoperative adjuvant dendritic cell-based immunotherapy in patients with relapsed glioblastoma multiforme. Clin Cancer Res. 2008; 14:3098-104. [PubMed: 18483377]

26. Liau LM, Prins RM, Kiertscher SM, Odesa SK, Kremen TJ, Giovannone AJ, et al. Dendritic cell vaccination in glioblastoma patients induces systemic and intracranial T-cell responses modulated by the local central nervous system tumor microenvironment. Clin Cancer Res. 2005; 11:5515-25. [PubMed: 16061868]

27. Wheeler CJ, Black KL, Liu G, Mazer M, Zhang XX, Pepkowitz S, et al. Vaccination elicits correlated immune and clinical responses in glioblastoma multiforme patients. Cancer Res. 2008; 68:5955-64. [PubMed: 18632651]

28. Yamanaka R, Homma J, Yajima N, Tsuchiya N, Sano M, Kobayashi T, et al. Clinical evaluation of dendritic cell vaccination for patients with recurrent glioma: results of a clinical phase I/II trial. Clin Cancer Res. 2005; 11:4160-7. [PubMed: 15930352]

29. Yu JS, Wheeler CJ, Zeltzer PM, Ying H, Finger DN, Lee PK, et al. Vaccination of malignant glioma patients with peptide-pulsed dendritic cells elicits systemic cytotoxicity and intracranial Tcell infiltration. Cancer Res. 2001; 61:842-7. [PubMed: 11221866]

30. Sampson JH, Heimberger AB, Archer GE, Aldape KD, Friedman AH, Friedman HS, et al. Immunologic escape after prolonged progression-free survival with epidermal growth factor receptor variant III peptide vaccination in patients with newly diagnosed glioblastoma. J Clin Oncol. 2010; 28:4722-9. [PubMed: 20921459]

31. de Vries IJ, Lesterhuis WJ, Barentsz JO, Verdijk P, van Krieken JH, Boerman OC, et al. Magnetic resonance tracking of dendritic cells in melanoma patients for monitoring of cellular therapy. Nat Biotechnol. 2005; 23:1407-13. [PubMed: 16258544]

32. Morse MA, Coleman RE, Akabani G, Niehaus N, Coleman D, Lyerly HK. Migration of human dendritic cells after injection in patients with metastatic malignancies. Cancer Res. 1999; 59:56-8. [PubMed: 9892184]

33. Chang CN, Huang YC, Yang DM, Kikuta K, Wei KJ, Kubota T, Yang WK. A phase I/II clinical trial investigating the adverse and therapeutic effects of a postoperative autologous dendritic cell tumor vaccine in patients with malignant glioma. J Clin Neurosci. 2011; 18:1048-54. [PubMed: 21715171]

34. Cho DY, Yang WK, Lee HC, Hsu DM, Lin HL, Lin SZ, et al. Adjuvant immunotherapy with whole-cell lysate dendritic cells vaccine for glioblastoma multiforme: a phase II clinical trial. World Neurosurg. 2012; 77:736-44. [PubMed: 22120301]

35. Yu JS, Liu G, Ying H, Yong WH, Black KL, Wheeler CJ. Vaccination with tumor lysate-pulsed dendritic cells elicits antigen-specific, cytotoxic T-cells in patients with malignant glioma. Cancer Res. 2004; 64:4973-9. [PubMed: 15256471]

36. Ardon H, De Vleeschouwer S, Van Calenbergh F, Claes L, Kramm CM, Rutkowski S, et al. Adjuvant dendritic cell-based tumour vaccination for children with malignant brain tumours. Pediatr Blood Cancer. 2010; 54:519-25. [PubMed: 19852061] 
37. Caruso DA, Orme LM, Neale AM, Radcliff FJ, Amor GM, Maixner W, et al. Results of a phase 1 study utilizing monocyte-derived dendritic cells pulsed with tumor RNA in children and young adults with brain cancer. Neuro Oncol. 2004; 6:236-46. [PubMed: 15279716]

38. Nagane M, Coufal F, Lin H, Bogler O, Cavenee WK, Huang HJ. A common mutant epidermal growth factor receptor confers enhanced tumorigenicity on human glioblastoma cells by increasing proliferation and reducing apoptosis. Cancer Res. 1996; 56:5079-86. [PubMed: 8895767]

39. Nishikawa R, Ji XD, Harmon RC, Lazar CS, Gill GN, Cavenee WK, Huang HJ. A mutant epidermal growth factor receptor common in human glioma confers enhanced tumorigenicity. Proc Natl Acad Sci U S A. 1994; 91:7727-31. [PubMed: 8052651]

40. Heimberger AB, Crotty LE, Archer GE, Hess KR, Wikstrand CJ, Friedman AH, et al. Epidermal growth factor receptor VIII peptide vaccination is efficacious against established intracerebral tumors. Clin Cancer Res. 2003; 9:4247-54. [PubMed: 14519652]

41. Sampson JH, Archer GE, Mitchell DA, Heimberger AB, Herndon JE 2nd, Lally-Goss D, et al. An epidermal growth factor receptor variant III-targeted vaccine is safe and immunogenic in patients with glioblastoma multiforme. Mol Cancer Ther. 2009; 8:2773-9. [PubMed: 19825799]

42. Bax DA, Gaspar N, Little SE, Marshall L, Perryman L, Regairaz M, et al. EGFRvIII deletion mutations in pediatric high-grade glioma and response to targeted therapy in pediatric glioma cell lines. Clin Cancer Res. 2009; 15:5753-61. [PubMed: 19737945]

43. Li G, Mitra SS, Monje M, Henrich KN, Bangs CD, Nitta RT, Wong AJ. Expression of epidermal growth factor variant III (EGFRvIII) in pediatric diffuse intrinsic pontine gliomas. J Neurooncol. 2012; 108:395-402. [PubMed: 22382786]

44. Moscatello DK, Holgado-Madruga M, Godwin AK, Ramirez G, Gunn G, Zoltick PW, et al. Frequent expression of a mutant epidermal growth factor receptor in multiple human tumors. Cancer Res. 1995; 55:5536-9. [PubMed: 7585629]

45. van Duivenvoorde LM, van Mierlo GJ, Boonman ZF, Toes RE. Dendritic cells: vehicles for tolerance induction and prevention of autoimmune diseases. Immunobiology. 2006; 211:627-32. [PubMed: 16920501]

46. Bielamowicz K, Khawja S, Ahmed N. Adoptive cell therapies for glioblastoma. Front Oncol. 2013; 3:275. [PubMed: 24273748]

47. Hegde M, Bielamowicz KJ, Ahmed N. Novel approaches and mechanisms of immunotherapy for glioblastoma. Discov Med. 2014; 17:145-54. [PubMed: 24641957]

48. Tzahar E, Pinkas-Kramarski R, Moyer JD, Klapper LN, Alroy I, Levkowitz G, et al. Bivalence of EGF-like ligands drives the ErbB signaling network. EMBO J. 1997; 16:4938-50. [PubMed: 9305636]

49. Zhang JG, Eguchi J, Kruse CA, Gomez GG, Fakhrai H, Schroter S, et al. Antigenic profiling of glioma cells to generate allogeneic vaccines or dendritic cell-based therapeutics. Clin Cancer Res. 2007; 13:566-75. [PubMed: 17255279]

50. Gilbertson RJ, Pearson AD, Perry RH, Jaros E, Kelly PJ. Prognostic significance of the c-erbB-2 oncogene product in childhood medulloblastoma. Br J Cancer. 1995; 71:473-7. [PubMed: 7880726]

51. Press MF, Cordon-Cardo C, Slamon DJ. Expression of the HER-2/neu proto-oncogene in normal human adult and fetal tissues. Oncogene. 1990; 5:953-62. [PubMed: 1973830]

52. Gilbertson RJ, Perry RH, Kelly PJ, Pearson AD, Lunec J. Prognostic significance of HER2 and HER4 coexpression in childhood medulloblastoma. Cancer Res. 1997; 57:3272-80. [PubMed: 9242460]

53. Ebb D, Meyers P, Grier H, Bernstein M, Gorlick R, Lipshultz SE, et al. Phase II trial of trastuzumab in combination with cytotoxic chemotherapy for treatment of meta-static osteosarcoma with human epidermal growth factor receptor 2 overexpression: a report from the Children's Oncology Group. J Clin Oncol. 2012; 30:2545-51. [PubMed: 22665540]

54. Ahmed N, Ratnayake M, Savoldo B, Perlaky L, Dotti G, Wels WS, et al. Regression of experimental medulloblastoma following transfer of HER2-specific T cells. Cancer Res. 2007; 67:5957-64. [PubMed: 17575166] 
55. Ahmed N, Salsman VS, Kew Y, Shaffer D, Powell S, Zhang YJ, et al. HER2-specific T cells target primary glioblastoma stem cells and induce regression of autologous experimental tumors. Clin Cancer Res. 2010; 16:474-85. [PubMed: 20068073]

56. Ahmed N, Salsman VS, Yvon E, Louis CU, Perlaky L, Wels WS, et al. Immunotherapy for osteosarcoma: genetic modification of T cells overcomes low levels of tumor antigen expression. Mol Ther. 2009; 17:1779-87. [PubMed: 19532139]

57. Wang LX, Westwood JA, Moeller M, Duong CP, Wei WZ, Malaterre J, et al. Tumor ablation by gene-modified T cells in the absence of autoimmunity. Cancer Res. 2010; 70:9591-8. [PubMed: 21098715]

58. Mitchell DA, Xie W, Schmittling R, Learn C, Friedman A, McLendon RE, Sampson JH. Sensitive detection of human cytomegalovirus in tumors and peripheral blood of patients diagnosed with glioblastoma. Neuro Oncol. 2008; 10:10-8. [PubMed: 17951512]

59. Scheurer ME, Bondy ML, Aldape KD, Albrecht T, El-Zein R. Detection of human cytomegalovirus in different histological types of gliomas. Acta Neuropathol. 2008; 116:79-86. [PubMed: 18351367]

60. Pule MA, Savoldo B, Myers GD, Rossig C, Russell HV, Dotti G, et al. Virus-specific T cells engineered to coexpress tumor-specific receptors: persistence and antitumor activity in individuals with neuroblastoma. Nat Med. 2008; 14:1264-70. [PubMed: 18978797]

61. Debinski W, Gibo DM, Hulet SW, Connor JR, Gillespie GY. Receptor for interleukin 13 is a marker and therapeutic target for human high-grade gliomas. Clin Cancer Res. 1999; 5:985-90. [PubMed: 10353730]

62. Jarboe JS, Johnson KR, Choi Y, Lonser RR, Park JK. Expression of interleukin-13 receptor alpha2 in glioblastoma multiforme: implications for targeted therapies. Cancer Res. 2007; 67:7983-6. [PubMed: 17804706]

63. Fujisawa T, Joshi B, Nakajima A, Puri RK. A novel role of interleukin-13 receptor alpha2 in pancreatic cancer invasion and metastasis. Cancer Res. 2009; 69:8678-85. [PubMed: 19887609]

64. Fujisawa T, Joshi BH, Puri RK. IL-13 regulates cancer invasion and metastasis through IL-13Ralpha2 via ERK/AP-1 pathway in mouse model of human ovarian cancer. Int J Cancer. 2012; 131:344-56. [PubMed: 21858811]

65. Brown CE, Starr R, Aguilar B, Shami AF, Martinez C, D'Apuzzo M, et al. Stem-like tumorinitiating cells isolated from IL13Ralpha2 expressing gliomas are targeted and killed by IL13zetakine-redirected T cells. Clin Cancer Res. 2012; 18:2199-209. [PubMed: 22407828]

66. Kahlon KS, Brown C, Cooper LJ, Raubitschek A, Forman SJ, Jensen MC. Specific recognition and killing of glioblastoma multiforme by interleukin 13-zetakine redirected cytolytic T cells. Cancer Res. 2004; 64:9160-6. [PubMed: 15604287]

67. Joshi BH, Puri RA, Leland P, Varricchio F, Gupta G, Kocak M, et al. Identification of interleukin-13 receptor alpha2 chain overexpression in situ in high-grade diffusely infiltrative pediatric brainstem glioma. Neuro Oncol. 2008; 10:265-74. [PubMed: 18430795]

68. Okada H, Low KL, Kohanbash G, McDonald HA, Hamilton RL, Pollack IF. Expression of gliomaassociated antigens in pediatric brain stem and non-brain stem gliomas. J Neurooncol. 2008; 88:245-50. [PubMed: 18324354]

69. Yeung JT, Hamilton RL, Okada H, Jakacki RI, Pollack IF. Increased expression of tumorassociated antigens in pediatric and adult ependymomas: implication for vaccine therapy. $\mathbf{J}$ Neurooncol. 2013; 111:103-11. [PubMed: 23179498]

70. Chow KK, Naik S, Kakarla S, Brawley VS, Shaffer DR, Yi Z, et al. T cells redirected to EphA2 for the immunotherapy of glioblastoma. Mol Ther. 2013; 21:629-37. [PubMed: 23070117]

71. Hegde M, Corder A, Chow KK, Mukherjee M, Ashoori A, Kew Y, et al. Combinational targeting offsets antigen escape and enhances effector functions of adoptively transferred $\mathrm{T}$ cells in glioblastoma. Mol Ther. 2013; 21:2087-101. [PubMed: 23939024]

72. Grada Z, Hegde M, Byrd T, Shaffer DR, Ghazi A, Brawley VS, et al. TanCAR: a novel bispecific chimeric antigen receptor for cancer immunotherapy. Mol Ther Nucleic Acids. 2013; 2:e105. [PubMed: 23839099]

73. Alvarez-Rueda N, Desselle A, Cochonneau D, Chaumette T, Clemenceau B, Leprieur S, et al. A monoclonal antibody to O-acetyl-GD2 ganglioside and not to GD2 shows potent anti-tumor 
activity without peripheral nervous system cross-reactivity. PLoS One. 2011; 6:e25220. [PubMed: 21966461]

74. Hank JA, Robinson RR, Surfus J, Mueller BM, Reisfeld RA, Cheung NK, Sondel PM. Augmentation of antibody dependent cell mediated cytotoxicity following in vivo therapy with recombinant interleukin 2. Cancer Res. 1990; 50:5234-9. [PubMed: 2386933]

75. Heczey A, Louis CU. Advances in chimeric antigen receptor immunotherapy for neuroblastoma. Discov Med. 2013; 16:287-94. [PubMed: 24333408]

76. Johnson E, Dean SM, Sondel PM. Antibody-based immunotherapy in high-risk neuroblastoma. Expert Rev Mol Med. 2007; 9:1-21. [PubMed: 18081947]

77. Park JR, Digiusto DL, Slovak M, Wright C, Naranjo A, Wagner J, et al. Adoptive transfer of chimeric antigen receptor re-directed cytolytic T lymphocyte clones in patients with neuroblastoma. Mol Ther. 2007; 15:825-33. [PubMed: 17299405]

78. Schonmann SM, Iyer J, Laeng H, Gerber HA, Kaser H, Blaser K. Production and characterization of monoclonal antibodies against human neuroblastoma. Int J Cancer. 1986; 37:255-62. [PubMed: 3943922]

79. Zhao XJ, Cheung NK. GD2 oligosaccharide: target for cytotoxic T lymphocytes. J Exp Med. 1995; 182:67-74. [PubMed: 7540657]

80. Yu AL, Gilman AL, Ozkaynak MF, London WB, Kreissman SG, Chen HX, et al. Anti-GD2 antibody with GM-CSF, interleukin-2, and isotretinoin for neuroblastoma. N Engl J Med. 2010; 363:1324-34. [PubMed: 20879881]

81. Louis CU, Brenner MK. Cellular immunotherapy for neuroblastoma: a review of current vaccine and adoptive T cell therapeutics. Curr Pharm Des. 2009; 15:424-9. [PubMed: 19199969]

82. Bowman L, Grossmann M, Rill D, Brown M, Zhong WY, Alexander B, et al. IL-2 adenovectortransduced autologous tumor cells induce antitumor immune responses in patients with neuroblastoma. Blood. 1998; 92:1941-9. [PubMed: 9731051]

83. Bowman LC, Grossmann M, Rill D, Brown M, Zhong WY, Alexander B, et al. Interleukin-2 genemodified allogeneic tumor cells for treatment of relapsed neuroblastoma. Hum Gene Ther. 1998; 9:1303-11. [PubMed: 9650615]

84. Caruso DA, Orme LM, Amor GM, Neale AM, Radcliff FJ, Downie P, et al. Results of a phase I study utilizing monocyte-derived dendritic cells pulsed with tumor RNA in children with stage 4 neuroblastoma. Cancer. 2005; 103:1280-91. [PubMed: 15693021]

85. Geiger JD, Hutchinson RJ, Hohenkirk LF, McKenna EA, Yanik GA, Levine JE, et al. Vaccination of pediatric solid tumor patients with tumor lysate-pulsed dendritic cells can expand specific $\mathrm{T}$ cells and mediate tumor regression. Cancer Res. 2001; 61:8513-9. [PubMed: 11731436]

86. Rousseau RF, Haight AE, Hirschmann-Jax C, Yvon ES, Rill DR, Mei Z, et al. Local and systemic effects of an allogeneic tumor cell vaccine combining transgenic human lymphotactin with interleukin-2 in patients with advanced or refractory neuroblastoma. Blood. 2003; 101:1718-26. [PubMed: 12406881]

87. Rousseau RF, Brenner MK. Vaccine therapies for pediatric malignancies. Cancer J. 2005; 11:3319. [PubMed: 16197723]

88. Di Stasi A, Tey SK, Dotti G, Fujita Y, Kennedy-Nasser A, Martinez C, et al. Inducible apoptosis as a safety switch for adoptive cell therapy. N Engl J Med. 2011; 365:1673-83. [PubMed: 22047558]

89. Louis CU, Savoldo B, Dotti G, Pule M, Yvon E, Myers GD, et al. Antitumor activity and longterm fate of chimeric antigen receptor-positive $\mathrm{T}$ cells in patients with neuroblastoma. Blood. 2011; 118:6050-6. [PubMed: 21984804]

90. Porter DL, Levine BL, Kalos M, Bagg A, June CH. Chimeric antigen receptor-modified T cells in chronic lymphoid leukemia. N Engl J Med. 2011; 365:725-33. [PubMed: 21830940]

91. Jensen MC, Riddell SR. Design and implementation of adoptive therapy with chimeric antigen receptor-modified T cells. Immunol Rev. 2014; 257:127-44. [PubMed: 24329794]

92. Toniatti C, Bujard H, Cortese R, Ciliberto G. Gene therapy progress and prospects: transcription regulatory systems. Gene Ther. 2004; 11:649-57. [PubMed: 14985790]

93. Xu XJ, Tang YM. Cytokine release syndrome in cancer immunotherapy with chimeric antigen receptor engineered T cells. Cancer Lett. 2014; 343:172-8. [PubMed: 24141191] 
94. Straathof KC, Pule MA, Yotnda P, Dotti G, Vanin EF, Brenner MK, et al. An inducible caspase 9 safety switch for T-cell therapy. Blood. 2005; 105:4247-54. [PubMed: 15728125]

95. Leahomschi S, Molinsky J, Klanova M, Andera L, Peterka M, Gasova Z, et al. Multi-level disruption of the extrinsic apoptotic pathway mediates resistance of leukemia cells to TNF-related apoptosis-inducing ligand (TRAIL). Neoplasma. 2013; 60:223-31. [PubMed: 23259793]

96. Rebarz M, Marcelis L, Menand M, Cornut D, Moucheron C, Jabin I, Kirsch-De Mesmaeker A. Revisited photophysics and photochemistry of a Ru-TAP complex using chloride ions and a Calix[6]crypturea. Inorg Chem. 2014; 53:2635-44. [PubMed: 24533637]

97. Tjon AS, Jaadar H, van Gent R, van Kooten PJ, Achatbi N, Metselaar HJ, Kwekkeboom J. Prevention of immunoglobulin G immobilization eliminates artifactual stimulation of dendritic cell maturation by intravenous immunoglobulin in vitro. Transl Res. 2014; 163:557-64. [PubMed: 24491358]

98. Leen AM, Myers GD, Sili U, Huls MH, Weiss H, Leung KS, et al. Monoculture-derived T lymphocytes specific for multiple viruses expand and produce clinically relevant effects in immunocompromised individuals. Nat Med. 2006; 12:1160-6. http://dx.doi.org/10.1038/nm1475. [PubMed: 16998485]

99. Gurney, JG.; Swensen, AR.; Bulterys, M. Malignant bone tumors. In: Ries, LAG.; Smith, MA.; Gurney, JG.; Linet, M.; Tamra, T.; Young, JL.; Bunin, GR., editors. Cancer incidence and survival among children and adolescents: United States SEER program, 1975-1995 (NIH Pub. No. 99-4649). Bethesda, MD: National Cancer Institute; 1999.

100. Ries, LAG.; Smith, MA.; Gurney, JG.; Linet, M.; Tamra, T.; Young, JL.; Bunin, GR. Cancer incidence and survival among children and adolescents: United States SEER Program 1975-1995 (NIH Pub. No. 99-4649). Bethesda, MD: National Cancer Institute; 1999.

101. Thompson PA, Chintagumpala M. Targeted therapy in bone and soft tissue sarcoma in children and adolescents. Curr Oncol Rep. 2012; 14:197-205. [PubMed: 22302601]

102. Purohit S, Bhise R, Appachu S, Lakshmaiah KC, Govindbabu K. Systemic therapy in soft tissue sarcomas: past, present and future. Indian J Surg Oncol. 2011; 2:327-31. [PubMed: 23204790]

103. Taylor BS, Barretina J, Maki RG, Antonescu CR, Singer S, Ladanyi M. Advances in sarcoma genomics and new therapeutic targets. Nat Rev Cancer. 2011; 11:541-57. [PubMed: 21753790]

104. Dagher R, Long LM, Read EJ, Leitman SF, Carter CS, Tsokos M, et al. Pilot trial of tumorspecific peptide vaccination and continuous infusion interleukin-2 in patients with recurrent Ewing sarcoma and alveolar rhabdomyosarcoma: an inter-institute NIH study. Med Pediatr Oncol. 2002; 38:158-64. [PubMed: 11836714]

105. Mackall CL, Rhee EH, Read EJ, Khuu HM, Leitman SF, Bernstein D, et al. A pilot study of consolidative immuno-therapy in patients with high-risk pediatric sarcomas. Clin Cancer Res. 2008; 14:4850-8. [PubMed: 18676758]

106. Suminoe A, Matsuzaki A, Hattori H, Koga Y, Hara T. Immunotherapy with autologous dendritic cells and tumor antigens for children with refractory malignant solid tumors. Pediatr Transplant. 2009; 13:746-53. [PubMed: 19067917]

107. Jungbluth AA, Antonescu CR, Busam KJ, Iversen K, Kolb D, Coplan K, et al. Monophasic and biphasic synovial sarcomas abundantly express cancer/testis antigen NY-ESO-1 but not MAGEA1 or CT7. Int J Cancer. 2001; 94:252-6. [PubMed: 11668506]

108. Rocca A, Casu G, Sechi CS. Penetrating craniocerebral injuries. Report of two unusual cases. J Neurosurg Sci. 1987; 31:19-21. [PubMed: 3625285]

109. Gorlick R, Huvos AG, Heller G, Aledo A, Beardsley GP, Healey JH, Meyers PA. Expression of HER2/erbB-2 correlates with survival in osteosarcoma. J Clin Oncol. 1999; 17:2781-8. [PubMed: 10561353]

110. Rainusso N, Brawley VS, Ghazi A, Hicks MJ, Gottschalk S, Rosen JM, Ahmed N. Immunotherapy targeting HER2 with genetically modified $\mathrm{T}$ cells eliminates tumor-initiating cells in osteosarcoma. Cancer Gene Ther. 2012; 19:212-7. [PubMed: 22173710]

111. Chan AT, Teo PM, Johnson PJ. Nasopharyngeal carcinoma. Ann Oncol. 2002; 13:1007-15. [PubMed: 12176778]

112. Raab-Traub N. Epstein-Barr virus in the pathogenesis of NPC. Semin Cancer Biol. 2002; 12:43141. [PubMed: 12450729] 
113. Comoli P, Pedrazzoli P, Maccario R, Basso S, Carminati O, Labirio M, et al. Cell therapy of stage IV nasopharyngeal carcinoma with autologous Epstein-Barr virus-targeted cytotoxic T lymphocytes. J Clin Oncol. 2005; 23:8942-9. [PubMed: 16204009]

114. Straathof KC, Bollard CM, Popat U, Huls MH, Lopez T, Morriss MC, et al. Treatment of nasopharyngeal carcinoma with Epstein-Barr virus-specific T lymphocytes. Blood. 2005; 105:1898-904. [PubMed: 15542583]

115. Straathof KC, Leen AM, Buza EL, Taylor G, Huls MH, Heslop HE, et al. Characterization of latent membrane protein 2 specificity in CTL lines from patients with EBV-positive nasopharyngeal carcinoma and lymphoma. J Immunol. 2005; 175:4137-47. [PubMed: 16148164]

116. Louis CU, Straathof K, Bollard CM, Ennamuri S, Gerken C, Lopez TT, et al. Adoptive transfer of EBV-specific T cells results in sustained clinical responses in patients with locoregional nasopharyngeal carcinoma. J Immunother. 2010; 33:983-90. [PubMed: 20948438]

117. Louis CU, Straathof K, Bollard CM, Gerken C, Huls MH, Gresik MV, et al. Enhancing the in vivo expansion of adoptively transferred EBV-specific CTL with lymphodepleting CD45 monoclonal antibodies in NPC patients. Blood. 2009; 113:2442-50. [PubMed: 18971421]

118. Ruggeri L, Capanni M, Urbani E, Perruccio K, Shlomchik WD, Tosti A, et al. Effectiveness of donor natural killer cell alloreactivity in mismatched hematopoietic transplants. Science. 2002; 295:2097-100. [PubMed: 11896281]

119. Perez-Martinez A, Leung W, Munoz E, Iyengar R, Ramirez M, Vicario JL, et al. KIR-HLA receptor-ligand mismatch associated with a graft-versus-tumor effect in haploidentical stem cell transplantation for pediatric meta-static solid tumors. Pediatr Blood Cancer. 2009; 53:120-4. [PubMed: 19215002]

120. Metelitsa LS, Wu HW, Wang H, Yang Y, Warsi Z, Asgharzadeh S, et al. Natural killer T cells infiltrate neuroblastomas expressing the chemokine CCL2. J Exp Med. 2004; 199:1213-21. [PubMed: 15123743]

121. Metelitsa LS. Anti-tumor potential of type-I NKT cells against CD1d-positive and CD1d-negative tumors in humans. Clin Immunol. 2011; 140:119-29. [PubMed: 21095162]

122. Song L, Asgharzadeh S, Salo J, Engell K, Wu HW, Sposto R, et al. Valpha24-invariant NKT cells mediate antitumor activity via killing of tumor-associated macrophages. J Clin Invest. 2009; 119:1524-36. [PubMed: 19411762]

123. Liu D, Song L, Brawley VS, Robison N, Wei J, Gao X, et al. Medulloblastoma expresses CD1d and can be targeted for immunotherapy with NKT cells. Clin Immunol. 2013; 149:55-64. [PubMed: 23891738]

124. Dudley ME, Yang JC, Sherry R, Hughes MS, Royal R, Kammula U, et al. Adoptive cell therapy for patients with metastatic melanoma: evaluation of intensive myeloablative chemoradiation preparative regimens. J Clin Oncol. 2008; 26:5233-9. [PubMed: 18809613]

125. Hayes RL, Koslow M, Hiesiger EM, Hymes KB, Hochster HS, Moore EJ, et al. Improved long term survival after intracavitary interleukin-2 and lymphokine-activated killer cells for adults with recurrent malignant glioma. Cancer. 1995; 76:840-52. [PubMed: 8625188]

126. Quattrocchi KB, Miller CH, Cush S, Bernard SA, Dull ST, Smith M, et al. Pilot study of local autologous tumor infiltrating lymphocytes for the treatment of recurrent malignant gliomas. $\mathrm{J}$ Neurooncol. 1999; 45:141-57. [PubMed: 10778730] 
HEGDE et al.

Page 20

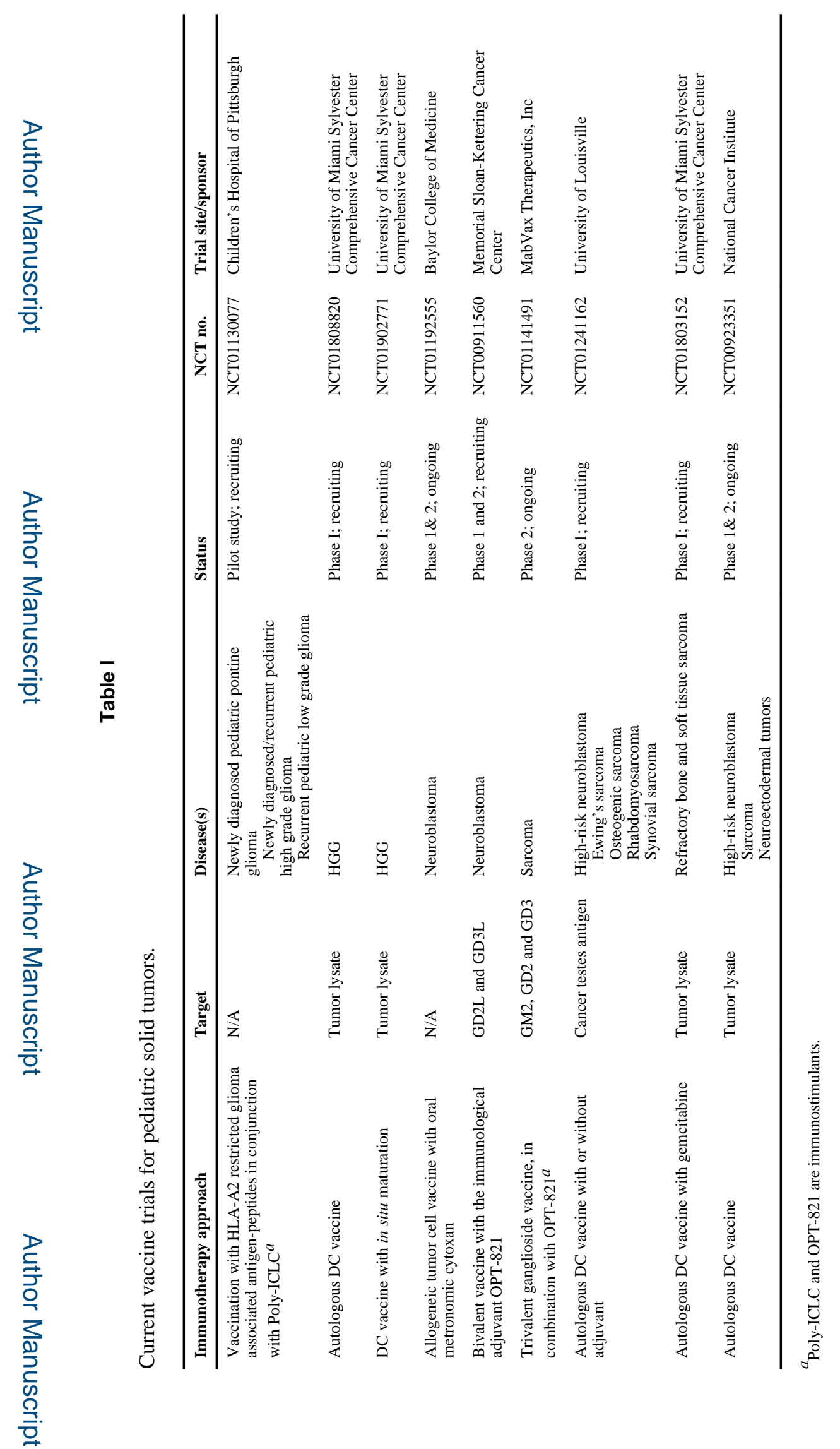

Cytotherapy. Author manuscript; available in PMC 2016 January 01. 


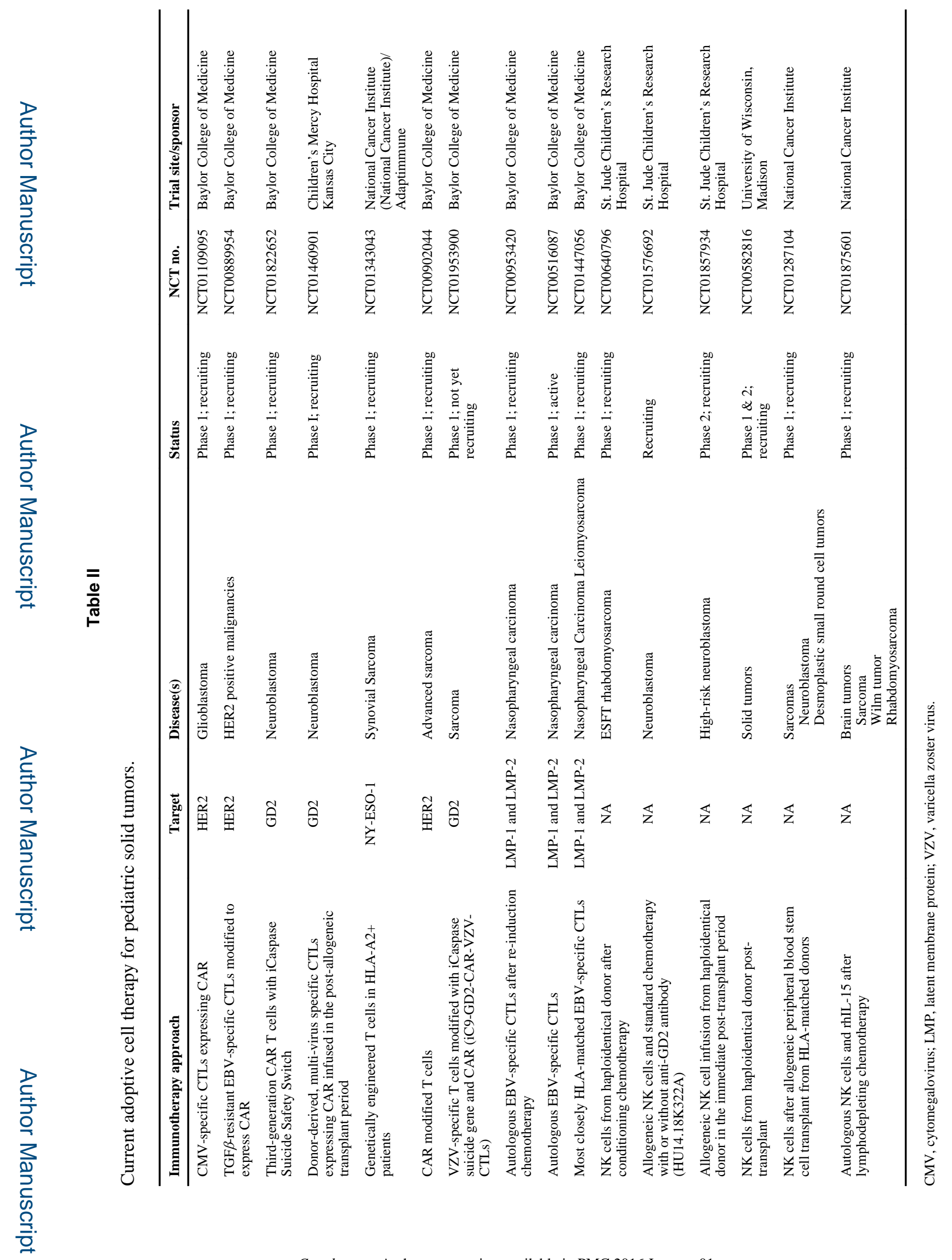

Cytotherapy. Author manuscript; available in PMC 2016 January 01. 